\title{
THE TREND OF THE RETURNS TO EDUCATIONS IN INDONESIA
}

\author{
${ }^{1}$ Nenny Hendajany, ${ }^{2}$ Tri Widodo, ${ }^{2}$ Eny Sulistyaningrum \\ ${ }^{1}$ Economic and Business Faculty, Sangga Buana University \\ PHH Mustafa No 68, Bandung, Phone +62-022-7275489 \\ ${ }^{2}$ Economics and Business Faculty, Gadjah Mada University \\ Jalan Sosio Humaniora Bulaksumur, Yogyakarta 55281, Indonesia \\ Correspondence E-mail: nennyhendajany@gmail.com
}

Recieved: February 2016; Accepted: June 2016

\begin{abstract}
This paper describes the rate of return to education in Indonesia. The purpose of this paper was to determine how the trend of return to education from 1993 to 2007. By using Mincer equation, we analyzed return to education in Indonesia with using Indonesia Family Life Survey (IFLS) data collected in 1993, 1997, 2000, and 2007. Mincer specification linked between income and education. Income used in this paper was real income of a person who works. The estimation of the rate of return to education started by separating each year data. Then, it used pool data by adding year variable and multiplication variable between year and education. Estimation was also carried out by comparing between men and women. Further, estimation was divided into two age cohorts, young cohort and old cohort. All the results of estimation indicated a decreasing rate of return, the greatest decrease occurred on men with old cohort.
\end{abstract}

Keywords: education, return to education, Mincer equation, trend JEL Classification: I26, J30

\section{Introduction}

Education plays a role in increasing a person's income. Individuals with high education tend to have greater income compared with individuals with low education when entering the market of labor. High income makes individual welfare increased. Increased individual welfare is also expected to improve the welfare of society. Mankiw, Romer and Weil (1992) mentioned the importance of the role of education in increasing the welfare of the country.

The relationship between individual's education and income has been widely demonstrated in numerous studies. Education is individual's investment at the school age and they will get return when entering into the workplace. The amount of private return gained by someone from educational investment is generally known as return to education.

Indonesia through 6 years of compulsory education program began in 1984 attempts to improve the quality of education in the society. This program is started by the construction of $S D$ Inpres (Presidential Instruction for the establishment of rural public schools) in 1973. Since the issuance of Presidential Instruction No. 1 of 1994 on the Implementation of Compulsory Elementary Education, then the compulsory education increases to 9 years. Currently, the issue about increasing education to 12 years compulsory education is being raised. This government program is expected to increase school participation rates (Angka Partisipasi Sekolah/APS) and the quality of public education. 


\section{Jurnal Ekonomi Pembangunan, 17 (1), Juni 2016, 62-73}

Based on data from Badan Pusat Statistik (BPS), APS in Indonesia increased from year to year. This indicates that public interest to attend the school also increased. Similarly based on IFLS data, the average years of education for age over 15 years old increased from 1993 to 2007. The average years of education increased from 6.70 years with standard deviation of 4.60 years in 1993 to 8.20 years with standard deviation of 4.44 years in 2007 .
Table 1 shows the distribution of education in Indonesia in the age between 15-65 years old based on data IFLS1, IFLS2, IFLS3, and IFLS4. These data show the increasing quality of education as seen from years of education. The median value of distribution of education in Indonesia has increased from the level of elementary school (6 years) in 1993 to the level of junior high school (9 years) in 2007.

Table 1. IFLS-based Distribution of Education for Age Category of 15-65

\begin{tabular}{ccccccccc}
\hline $\begin{array}{c}\text { Years of School } \\
\text { Completion }\end{array}$ & \multicolumn{2}{c}{$\mathbf{1 9 9 3}$} & \multicolumn{2}{c}{$\mathbf{1 9 9 7}$} & \multicolumn{2}{c}{$\mathbf{2 0 0 0}$} & \multicolumn{2}{c}{$\mathbf{2 0 0 7}$} \\
\cline { 2 - 9 } & $\mathbf{\%}$ & $\mathbf{C u m} \mathbf{\%}$ & $\mathbf{\%}$ & $\mathbf{C u m} \mathbf{\%}$ & $\mathbf{\%}$ & $\mathbf{C u m} \mathbf{\%}$ & $\mathbf{\%}$ & Cum \% \\
\hline 0 & 14,89 & 14,89 & 11,56 & 11,56 & 8,88 & 8,88 & 6,13 & 6,13 \\
1 & 4,31 & 19,21 & 2,76 & 14,32 & 2,79 & 11,67 & 2,29 & 8,42 \\
2 & 5,65 & 24,85 & 4,1 & 18,42 & 3,6 & 15,27 & 2,7 & 11,12 \\
3 & 5,43 & 30,28 & 4,38 & 22,8 & 3,51 & 18,78 & 2,78 & 13,9 \\
4 & 4,68 & 34,96 & 3,81 & 26,61 & 3,41 & 22,19 & 2,74 & 16,64 \\
5 & 3,24 & 38,2 & 2,59 & 29,2 & 2,16 & 24,35 & 1,86 & 18,5 \\
6 & 20,76 & 58,96 & 23,25 & 52,45 & 22,22 & 46,57 & 20,35 & 38,85 \\
7 & 3,17 & 62,13 & 2,12 & 54,56 & 2,04 & 48,61 & 1,96 & 40,81 \\
8 & 3,05 & 65,18 & 2,67 & 57,24 & 2,4 & 51,01 & 2,22 & 43,03 \\
9 & 8,93 & 74,11 & 13,21 & 70,44 & 14,46 & 65,47 & 15,97 & 59 \\
10 & 4,51 & 78,62 & 2,45 & 72,9 & 2,48 & 67,95 & 2,2 & 61,21 \\
11 & 2,42 & 81,04 & 2,34 & 75,24 & 2,38 & 70,33 & 1,93 & 63,13 \\
12 & 13,55 & 94,59 & 18,13 & 93,37 & 21,07 & 91,4 & 25,62 & 88,75 \\
13 & 1,24 & 95,83 & 0,73 & 94,1 & 0,85 & 92,26 & 0,84 & 89,6 \\
14 & 0,84 & 96,67 & 1,41 & 95,5 & 3,52 & 95,78 & 4,1 & 93,69 \\
15 & 1,39 & 98,06 & 1,73 & 97,23 & 0,46 & 96,24 & 0,53 & 94,22 \\
16 & 1,94 & 100 & 2,7 & 99,93 & 3,59 & 99,83 & 5,41 & 99,63 \\
17 & - & - & - & - & 0,05 & 99,87 & 0,04 & 99,67 \\
$18+$ & - & - & 0,07 & 100 & 0,13 & 100 & 0,33 & 100 \\
\hline
\end{tabular}

Source: IFLS 1993, 1997, 2000 and 2007, processed

The purpose of this paper is to explain how the value of return to education from year to year in Indonesia. It is based on an increase in APS and an increase in the average years of education based on IFLS data. The author wants to determine whether the increase in the quality of education as seen from the school duration in providing the influence for an increase/decrease in the rate of return to education.
Some researches on changes or trend of return to education that have been examined provided the result which tended to decrease (Fersterer and Winter-Ebmer, 2003; SelzLaurière and Thélot, 2004). The different result was shown by Xiaohao and Suhong (2013) where the value of rate of return to education was getting increase. While Purnastuti, Miler, and Salim (2013) found evidence of an increased rate 


\section{Jurnal Ekonomi Pembangunan, 17 (1), Juni 2016, 62-73}

of return to education from 1993 to 2007 with using IFLS 1 and IFLS 4 data for higher education and a decrease of other educational levels. These motivate the author to find out more about how the trend of return to education in Indonesia from 1993, 1997, 2000, and 2007.

Blundell, Dearden, and Sianesi (2001) stated that there were three different sides in defining the return of education, namely: private return, social return and labor productivity return. In the other writing of Blundell, Dearden, Goodman, and Reed (2000), there were three categories of benefits or return of higher education, namely: private financial return, private non-financial return, and social return. The author focus only on the private return expressed in the form of individual's earning or focus on private financial return. Private return is return of education as a person's decision making to invest in human capital and explain the level of return on the investment.

Analysis of demand for education is developed from the concept of human capital pioneered by Gary Becker, Jacob Mincer and Theodore Schultz. According to the theory of human capital, education is an investment of the current resource expected to bring benefits in the future. Model of estimation development of return to education used as a benchmark by most researchers is a model made by Mincer (1974).

Harmon, Oosterbeek, and Walker (2003) explained how Mincer model was formed. Theory of human capital assumes that education (S) is chosen to maximize the present value from the flow of future income (W), until retirement period (T), after it is deducted by the cost of education (cs). When $\mathrm{S}$ is optimum, $\mathrm{PV}$ in the $\mathrm{S}$ school year will be equal to the cost of $\mathrm{S}$ school year, so as to obtain the equation:

$$
\sum_{t=1}^{T-S} \frac{W_{S}-W_{S-1}}{\left(1+r_{S}\right)^{t}}=W_{S-1}+c_{s}
$$

where $r_{S}$ is internal rate of return. Optimal investment decision-making will have implications on a person's decision to invest in education until the $\mathrm{S}$ year, if $r_{S}>\rho$, where $\rho$ is market interest rate. If $\mathrm{T}$ value is great, then $\sum_{t=1}^{T-S} \frac{1}{\left(1+r_{S}\right)^{t}}=\frac{1}{r_{S}}$,
so the above equation becomes:

$\frac{W_{S}-W_{S-1}}{r_{S}}=W_{S-1}+c_{S}$

If $C_{S}$ is very small, then the above equation can be simplified to:

$\frac{w_{S}-w_{S-1}}{r_{S}} \approx w_{S-1}$

or

$r_{S} \approx \frac{W_{S}-W_{S-1}}{W_{S-1}} \approx \log W_{S}-\log W_{S-1}$.

The equation means that the return of $\mathrm{S}$ school year is approached by the difference in the log wage/income between S and S-1 school years. In simple term, we can estimate the return of school by seeing how the log of income varies in the school years.

The empirical approach of framework of human capital theory in the form of function is commonly known as earnings function in the form:

$\log W_{i}=\alpha_{0}+r S_{i}+\delta E_{i}+\gamma E_{i}^{2}+\boldsymbol{X}_{i} \beta+u_{i}$

where $W_{i}$ is the individual income i, $S_{i}$ describes a size of school year of individual $i$, and $E_{i}$ is experience size. $\boldsymbol{X}_{i}$ is a set of variables that are assumed to influence earnings, and $u_{i}$ is a disturbance that represents a variable that cannot be measured explicitly, it is assumed to be independent with $\boldsymbol{X}_{i}$ and $S_{i}$. Equation (5) is a modification of the basic Mincer equation.

Psacharopoulos (1994) recorded the relative differences in human capital (knowledge and skills) that were higher in developing countries compared to developed countries. The rate of 


\section{Jurnal Ekonomi Pembangunan, 17 (1), Juni 2016, 62-73}

return of education for developing countries was higher than in developed countries (Psacharopoulos, 1981, 1994). This statement is supported by a summary of some researches on the value of return to education of Bils and Klenow (2000).

Fersterer and Winter-Ebmer (2003) used micro data in 1981-1997 to see the evolution trend of the rate of return to education in Austria. They found evidence of a trend that tended to decrease from return to education. The average return decreased from 10 percent in 1981 to 7.4 percent in 1997 for men, while for women decreased from 11.4 percent to 8 percent. This decrease was not due to changes in the sample design or a decrease in the willingness of a person to reveal his/her earning in the survey, but due to the decrease of return to education, especially at the university level. Fersterer and Winter-Ebmer used a simple method to make easy in comparing with the other researches. According to Fersterer and WinterEbmer, a simple method measured the return to education as a whole because all indirect influences of education (e.g. selection of work field and companies with the best reputation) on income were considered as a result of education itself directly.

Other research on trend returns to education was conducted by Selz-Laurière and Thélot (2004).

Selz-Laurière and Thélot observed trend returns to education for thirty five years in France. They evaluated the impact over the time on income from the duration of school and experience, besides they compared between women and men, and between the public and private sectors. Their research result proved the decrease of return to education for more than 20 years (1965-1985) and the next fifteen years was relatively stable. The model used by Selz-Laurière and Thélot (2004) was a simple model of earning function involving the duration of education and experience in the form of a third-degree polynomial.

Silles (2007) with the data of General Household Survey for women and men in U.K. in 1985-2003 found the decreasing value of return to education for women and the increasing value for men. Silles added educational qualities at Mincer equation and used age cohort. The conclusion obtained for men with all educational qualities was that young men have the increasing value of return, while old men were relatively stable. While for women with educational qualifications that were not too high was obtained the result that young women had decreasing value and old women was stable. While the women with high educational qualifications both for young and old women had the decreasing value.

Xiaohao and Suhong (2013) used Urban China data in 1988, 1995, and 2002 to observe the trend of return to education. They found that the return value was relatively lower than the average return in the world. However the rate of return to education showed the increasing value from year to year.

\section{Research Method}

The basic model of human capital income of Mincer (1974):

$\operatorname{Ln} w_{i}=\beta_{0}+\beta_{1} S_{i}+\beta_{2} E_{i}+\beta_{3} E_{i}^{2}+\varepsilon_{i}$,

where the parameter of $\beta_{1}$ is interpreted as rate of return from additional years of education. The model of human capital is estimated separately from 1993, 1997, 2000 and 2007.

The model of human capital is also estimated for all data and included additional variable of years dummy and interaction variable of years dummy in education. The specification becomes:

$$
L n w_{i}=\gamma_{0}+\gamma_{1} S_{i}+\gamma_{2}\left(S_{i} T_{i}\right)+\gamma_{3} E_{i}+\gamma_{4} E_{i}{ }^{2}+\gamma_{5} T_{i}+v_{i}
$$




\section{Jurnal Ekonomi Pembangunan, 17 (1), Juni 2016, 62-73}

where $\mathrm{T}$ is the year when the observation is conducted. Multiplication variable between education and years of trend to test whether there is a significant long-term difference in return over time. Equation (7) refers to the model used by Silles (2007).

Separation data between men and women are also conducted to see whether there are differences in the trend of return between men and women. In addition, the use of age cohort is carried out to distinguish between young and old women, or young and old men. Cohort is divided into the age under 40 years old and above 40 years old.

\section{Result and Discussion}

Data used in this research were obtained from IFLS 1993, 1997, 2000, and 2007. IFLS is a large-scale longitudinal observation of the individual and household level to survey socialeconomy and health. The criteria used are workers aged between 15 years old to 65 years old, have the latest education data, and no longer attending school.

The dependent variable used by the author is income per year. Income per year is obtained from a questionnaire with the question: "How much salary/wages or net income (salary, bonuses and allowance) for 12 months?" or "how much net profit earned on the job for 12 months?". The reason why the author does not use hourly earnings is because there is no question that directly leads to the hourly earnings in the questionnaire. The author needs to involve several other questions in the IFLS questionnaire to get the question of hourly earnings. However, if this is carried out, the author worries that it will lead to bias due to measurement error. The earning in this paper is the earning earned from work. This information is obtained in IFLS questionnaire Book 3A Section TK.

Variable of education uses the measurement of length/duration of a person in completing school (in year). This measurement is consistent with human capital theory. Data of school length in IFLS can be found in Book 3A section DL. The explanation of education duration in this research is consistent with IFLS questionnaire and the rules of education. The result is presented in Table 2.

Table 2. Duration of Education

\begin{tabular}{lc}
\hline Educational Attainment & $\begin{array}{c}\text { Duration of } \\
\text { Education } \\
\text { (years) }\end{array}$ \\
\hline No Schooling & 0 \\
Did not Complete/Have not & $1,2,3,4,5$ \\
Completed Primary School & 6 \\
Primary School & 6 \\
Packet A & 7,8 \\
Did not Complete/Have not & 9 \\
Completed Junior High School & 9 \\
Junior High School (General) & 9 \\
Junior High School (Vocational) & 10,11 \\
Packet B & 12 \\
Did not Complete/Have not & 12 \\
Completed Senior High School & 12 \\
Senior High School (General) & 14 \\
Senior High School (Vocational) & 15 \\
Packet C & 16 \\
Diploma I/II & 20 \\
Academy/Diploma III & \\
University & \\
Master/PhD & \\
\hline Note: Packet A, B, and are the & \\
\hline
\end{tabular}

Note: Packet A, B, and C are the informal school

Variable of experience is the number of years from the beginning of work as measured through approach, where is the age in years of data collection, is school duration, and is early age in school. Variable of experience with this approach is commonly called as the potential experience. Variable of age refers to book 3A, school duration is consistent with education variable, while early age in school is 7 years consistent with the rules of educational age on education system in Indonesia.

The average real income tends to rise except in 2000 which decrease due to the financial crisis that began in 1998. There are significant 


\section{Jurnal Ekonomi Pembangunan, 17 (1), Juni 2016, 62-73}

differences in the average of income between men and women. Variable of education as measured by the number of school years increases from year to year. The average of year of schooling in 1993 is 5.72 years and 8.44 years in 2007 . The differences between men and women education is quite significant in 1993 , but the difference is less significant in 2007. Detail information can be seen in Appendix 1.

\section{Result of Analysis}

The result of return to education with using equation (6) for each year separately is presented in Appendix 2. The trend of rate of return to education decreases from year to year. Rate of return to education is at 15.8 percent in 1993 , 14.1 percent in 1997, 13.4 percent in 2000 , and 13.3 percent in 2007.

The separation between men and women with using equation (6) describes rate of return to education are both decreased from year to year. Rate of return to education for men is at 15.2 percent in 1993, 13.0 percent in 1997, 12.5 percent in 2000 , and 12.3 percent in 2007 . Rate of return to education for women is at 16.9 percent in 1993 , 15.9 percent in $1997,14.8$ percent in 2000 , and 14.7 percent in 2007 . Women have a greater rate of return to education than men in the same year. The detail information can be seen in Table 3 and Table 4.

Table 3. Rate of Return to Education with Basic Mincer Specification for Men

\begin{tabular}{lcccc}
\hline & $\mathbf{1 9 9 3}$ & $\mathbf{1 9 9 7}$ & $\mathbf{2 0 0 0}$ & $\mathbf{2 0 0 7}$ \\
\hline educ & $0.152^{* * *}$ & $0.130^{* * *}$ & $0.125^{* * *}$ & $0.123^{* * *}$ \\
& $(0.00405)$ & $(0.00336)$ & $(0.00296)$ & $(0.00297)$ \\
$\exp$ & $0.0604^{* * *}$ & $0.0731^{* * *}$ & $0.0884^{* * *}$ & $0.0696^{* * *}$ \\
exp2 & $(0.00527)$ & $(0.00356)$ & $(0.00298)$ & $(0.00305)$ \\
& $-0.00096^{* * *}$ & $-0.00119^{* * *}$ & $-0.00142^{* * *}$ & $-0.00102^{* * *}$ \\
Constant & $(0.00009)$ & $(0.00007)$ & $(0.00006)$ & $(0.00006)$ \\
& $12.94^{* * *}$ & $13.09^{* * *}$ & $12.84^{* * *}$ & $13.09^{* * *}$ \\
Observations & $(0.0869)$ & $(0.056)$ & $(0.0459)$ & $(0.0493)$ \\
R-squared & 4,892 & 5,880 & 8,546 & 10,188 \\
\hline
\end{tabular}

Note: Dependent variable is income in year. The first line indicates coefficient value where the sign $* * *$ is significant $1 \%, * *$ is significant $5 \%$ and $*$ is significant $10 \%$. The second line indicates error standard.

Table 4. Rate of Return to Education with Basic Mincer Specification for Women

\begin{tabular}{lcccc}
\hline & $\mathbf{1 9 9 3}$ & $\mathbf{1 9 9 7}$ & $\mathbf{2 0 0 0}$ & $\mathbf{2 0 0 7}$ \\
\hline educ & $0.169^{* * *}$ & $0.159^{* * *}$ & $0.148^{* * *}$ & $0.147^{* * *}$ \\
& $(0.00655)$ & $(0.00472)$ & $(0.00436)$ & $(0.00426)$ \\
$\exp$ & $0.0546^{* * *}$ & $0.0507^{* * *}$ & $0.0515^{* * *}$ & $0.0426^{* * *}$ \\
exp2 & $(0.00787)$ & $(0.00418)$ & $(0.00356)$ & $(0.00364)$ \\
& $-0.00077^{* * *}$ & $-0.00067^{* * *}$ & $-0.00064^{* * *}$ & $-0.00051^{* * *}$ \\
Constant & $(0.00012)$ & $(0.00007)$ & $(0.00007)$ & $(0.00007)$ \\
& $12.34^{* * *}$ & $12.61^{* * *}$ & $12.48^{* * *}$ & $12.67^{* * *}$ \\
Observations & $(0.134)$ & $(0.0712)$ & $(0.0628)$ & $(0.0663)$ \\
R-squared & 2,540 & 3,625 & 5,298 & 5,950 \\
\hline
\end{tabular}

Note: Dependent variable is income in year. The first line indicates coefficient value where the sign *** is significant $1 \%, * *$ is significant $5 \%$ and $*$ is significant $10 \%$. The second line indicates error standard. 


\section{Jurnal Ekonomi Pembangunan, 17 (1), Juni 2016, 62-73}

The use of young and old age cohort shows that young age cohort has greater value of return to education than old age cohort. For example, young age cohort has rate of return of education of 17.3 percent, while old age cohort is 14.8 percent in 1993. Men with young cohort have greater return value than men with old cohort, likewise for women. Detail information can be seen in Table 5 .

Table 5. Rate of Return to Education, Separation between Sex and Cohort

\begin{tabular}{lccccc}
\hline & & $\mathbf{1 9 9 3}$ & $\mathbf{1 9 9 7}$ & $\mathbf{2 0 0 0}$ & $\mathbf{2 0 0 7}$ \\
\hline \multirow{2}{*}{ Men } & Old & $0.146^{* * *}$ & $0.127^{* * *}$ & $0.0940^{* * * *}$ & $0.0946^{* * *}$ \\
& Young & $0.161^{* * *}$ & $0.131^{* * *}$ & $0.138^{* * *}$ & $0.137^{* * *}$ \\
\multirow{3}{*}{ All } & Old & $0.153^{* * *}$ & $0.139^{* * *}$ & $0.121^{* * *}$ & $0.120^{* * * *}$ \\
& Young & $0.192^{* * *}$ & $0.174^{* * *}$ & $0.161^{* * *}$ & $0.157^{* * *}$ \\
& Old & $0.148^{* * *}$ & $0.130^{* * *}$ & $0.103^{* * *}$ & $0.105^{* * * *}$ \\
& Young & $0.173^{* * *}$ & $0.149^{* * *}$ & $0.148^{* * *}$ & $0.146^{* * *}$ \\
\hline
\end{tabular}

Note: estimated rate of return to education with using basic Mincer equation with separation between sex and cohort. ${ }^{* * *}$ Significant 1 percent

The estimation result (7) with a pool of data also shows the trend of rate of return to education that are decreasing from year to year (see coefficient of educ*year). A decrease in rate of return for men is 1.2 percent, while for women is 0.9 percent. More results are shown in Table 6 .
The increase in income is 9.5 percent per year. The increase in income is greater for men than women. The increase in income is 11.8 percent for men while 6.7 percent for women. All the increase in income is significant at 1 percent.

Table 6. Rate of return to Education with Pool Data

\begin{tabular}{lccc}
\hline & Men & Women & All \\
\hline Educ & $0.163^{* * *}$ & $0.177^{* * *}$ & $0.167^{* * *}$ \\
& $(0.00391)$ & $(0.00548)$ & $(0.00319)$ \\
Educ*year & $-0.0117^{* * *}$ & $-0.00853^{* * *}$ & $-0.0101^{* * *}$ \\
Exp & $(0.00129)$ & $(0.00174)$ & $(0.00104)$ \\
& $0.0764^{* * *}$ & $0.0490^{* * *}$ & $0.0642^{* * *}$ \\
Exp2 & $(0.00171)$ & $(0.00209)$ & $(0.00133)$ \\
& $-0.00119^{* * *}$ & $-0.00063^{* * *}$ & $-0.00095^{* * *}$ \\
Year & $(0.00003)$ & $(0.00004)$ & $(0.00002)$ \\
& $0.118^{* * * *}$ & $0.0667^{* * *}$ & $0.0947^{* * *}$ \\
Sex & $(0.0116)$ & $(0.0149)$ & $(0.00919)$ \\
& & & $0.455^{* * *}$ \\
Constant & $12.63^{* * *}$ & $12.36^{* * *}$ & $(0.0108)$ \\
& $(0.041)$ & $(0.0532)$ & $12.27^{* * *}$ \\
Observations & 29,506 & 17,413 & $(0.000)$ \\
R-squared & 0.228 & 0.222 & 46,919 \\
\hline
\end{tabular}

Note: Dependent variable is income in year. The first line indicates coefficient value where the sign $* * *$ is significant $1 \%, * *$ is significant $5 \%$ and * is significant $10 \%$. The second line indicates error standard. 


\section{Jurnal Ekonomi Pembangunan, 17 (1), Juni 2016, 62-73}

The estimation results of rate of return to education with pool data and cohort are shown in Appendix 3. Old Cohort shows a tendency of a greater decreasing trend than young cohort. A decreasing trend of return on men is greater than on women either in old or young cohort.

Based on the age cohort, there is a high increase in income in old cohort. The increase in income is 15.3 percent for old cohort while 2.1 percent for young cohort. There is a high increase in income in men old cohort. The increase in income is 19.1 percent for men old cohort while 10.8 percent for women old cohort.

\section{Conclusion}

Some researches on trend return to education generally provide empirical evidence of the decreasing level of return to education from year to year. This indicates that quality of education in the labor market is increasing (Silles, 2007).

Empirical results of this paper show the trend of return to education that is also decreasing. These results are consistent with some researches in other countries such as the research of Fersterer and Winter-Ebmer (2003) in Austria, SelzLaurière and Thélot (2004) in France, and Silles (2007) in UK. The decreasing trend occurred in both men and women, these results are consistent with the empirical result of Winter-Ebmer (2003). When the result is compared between men and women, then the greatest decrease occurs on men. The use of age cohort shows that old men have the greatest decrease.

This result implies that the quality of education in the labor market has increased and there is gender inequality in the quality of education in Indonesia.

Disadvantage of this paper is the use of assumption that bias resulting from unobserved variable is considered constant each year, so that the magnitude of bias is considered the same from year to year. Due to the purpose of this research is determining the trend of rate of return, then the method used is Ordinary Least Square (OLS). Some researchers also used this method such as: Fersterer and Winter-Ebmer (2003), SelzLaurière and Thélot (2004), and Silles (2007). The other researches in the future are expected to use the method to determine how many bias caused by unobserved variable.

\section{Reference}

Bils, M., \& Klenow, P. J. (2000). Does schooling cause growth? American economic review, 1160-1183.

Blundell, R., Dearden, L., Goodman, A., \& Reed, H. (2000). The Returns to Higher Education in Britain: Evidence from a British Cohort. The Economic Journal, 110(461), F82-F99. doi: $10.2307 / 2565942$

Blundell, R., Dearden, L., \& Sianesi, B. (2001). Estimating the returns to education: Models, methods and results.

Fersterer, J., \& Winter-Ebmer, R. (2003). Are Austrian returns to education falling over time? Labour economics, 10(1), 73-89.

Harmon, C., Oosterbeek, H., \& Walker, I. (2003). The Returns to Education: Microeconomics. [Article]. Journal of economic surveys, 17(2), 115-156. doi: 10.1111/1467-6419.00191

Mankiw, N. G., Romer, D., \& Weil, D. N. (1992). A Contribution to the Empirics of Economic Growth. The Quarterly Journal of Economics, 107(2), 407-437. doi: 10.2307/2118477

Mincer, J. (1974). Schooling, Experience, and Earnings: Columbia University Press.

Psacharopoulos, G. (1981). Returns to education: an updated international comparison. Comparative education, 17(3), 321-341.

Psacharopoulos, G. (1994). Returns to investment in education: A global update. World development, 22(9), 1325-1343.

Purnastuti, L., Miller, P. W., \& Salim, R. (2013). Declining rates of return to education: evidence for Indonesia. Bulletin of Indonesian Economic Studies, 49(2), 213-236. 


\section{Jurnal Ekonomi Pembangunan, 17 (1), Juni 2016, 62-73}

Selz-Laurière, M., \& Thélot, C. (2004). The returns to education and experience: Trends in France over the last thirty-five years. Population (english edition), 59(1), 9-48.

Silles, M. A. (2007). The Returns to Education for The United Kingdom. Journal of Applied Economics, 10(2), 391-413.
Xiaohao, D., \& Suhong, Y. (2013). Trends in the Mincerian Rates of Return to Education in Urban China: 1989-2009. Frontiers of Education in China, 8(3), 378-397. 
Avalaible online at http://journals.ums.ac.id

Jurnal Ekonomi Pembangunan, 17 (1), Juni 2016, 62-73

\section{Appendix}

Appendix 1. Statistical Summary

\begin{tabular}{|c|c|c|c|c|c|c|c|}
\hline Year & & Variable & Obs & Mean & Std. Dev. & Min & Max \\
\hline \multirow[t]{13}{*}{1993} & Men & income & 4892 & 4525068 & 5904641 & 23541 & 56300000 \\
\hline & & logey & 4892 & 14.65 & 1.28 & 10.07 & 17.85 \\
\hline & & educ & 4892 & 6.16 & 4.35 & 0 & 16 \\
\hline & & $\exp$ & 4892 & 27.81 & 13.00 & 0 & 58 \\
\hline & Women & income & 2540 & 2781745 & 4375230 & 22002 & 50700000 \\
\hline & & logey & 2540 & 13.95 & 1.44 & 10.00 & 17.74 \\
\hline & & educ & 2540 & 4.88 & 4.52 & 0 & 16 \\
\hline & & $\exp$ & 2540 & 28.42 & 14.10 & 0 & 58 \\
\hline & All & income & 7432 & 3929261 & 5492904 & 22002 & 56300000 \\
\hline & & logey & 7432 & 14.41 & 1.38 & 10.00 & 17.85 \\
\hline & & educ & 7432 & 5.72 & 4.45 & 0 & 16 \\
\hline & & $\exp$ & 7432 & 28.02 & 13.39 & 0 & 58 \\
\hline & & sex & 7432 & 0.66 & 0.47 & 0 & 1 \\
\hline \multirow[t]{13}{*}{1997} & Men & income & 5880 & 4777493 & 5217932 & 42901 & 45700000 \\
\hline & & logey & 5880 & 14.84 & 1.14 & 10.67 & 17.64 \\
\hline & & educ & 5880 & 6.99 & 4.33 & 0 & 21 \\
\hline & & $\exp$ & 5880 & 24.35 & 14.02 & 0 & 58 \\
\hline & Women & income & 3625 & 3074796 & 3966584 & 38276 & 38300000 \\
\hline & & logey & 3625 & 14.27 & 1.24 & 10.55 & 17.46 \\
\hline & & educ & 3625 & 6.19 & 4.66 & 0 & 19 \\
\hline & & $\exp$ & 3625 & 24.04 & 15.00 & 0 & 58 \\
\hline & All & income & 9505 & 4128121 & 4850318 & 38276 & 45700000 \\
\hline & & logey & 9505 & 14.62 & 1.21 & 10.55 & 17.64 \\
\hline & & educ & 9505 & 6.68 & 4.47 & 0 & 21 \\
\hline & & $\exp$ & 9505 & 24.23 & 14.40 & 0 & 58 \\
\hline & & sex & 9505 & 0.62 & 0.49 & 0 & 1 \\
\hline \multirow[t]{12}{*}{2000} & Men & income & 8546 & 4554587 & 5424095 & 40000 & 52000000 \\
\hline & & logey & 8546 & 14.78 & 1.13 & 10.60 & 17.77 \\
\hline & & educ & 8546 & 7.76 & 4.26 & 0 & 18 \\
\hline & & $\exp$ & 8546 & 21.46 & 14.01 & 0 & 58 \\
\hline & Women & income & 5298 & 2947824 & 4235143 & 40000 & 52500000 \\
\hline & & logey & 5298 & 14.18 & 1.27 & 10.60 & 17.78 \\
\hline & & educ & 5298 & 6.78 & 4.65 & 0 & 18 \\
\hline & & $\exp$ & 5298 & 22.91 & 15.03 & 0 & 58 \\
\hline & All & income & 13844 & 3939690 & 5063017 & 40000 & 52500000 \\
\hline & & logey & 13844 & 14.55 & 1.22 & 10.60 & 17.78 \\
\hline & & educ & 13844 & 7.38 & 4.44 & 0 & 18 \\
\hline & & $\exp$ & 13844 & 22.01 & 14.43 & 0 & 58 \\
\hline
\end{tabular}


Avalaible online at http://journals.ums.ac.id

Jurnal Ekonomi Pembangunan, 17 (1), Juni 2016, $62-73$

\begin{tabular}{|c|c|c|c|c|c|c|c|}
\hline 2007 & Men & $\begin{array}{l}\text { sex } \\
\text { income }\end{array}$ & $\begin{array}{l}13844 \\
10188\end{array}$ & $\begin{array}{c}0.62 \\
5546703\end{array}$ & $\begin{array}{c}0.49 \\
6164714\end{array}$ & $\begin{array}{c}0 \\
36361 \\
\end{array}$ & $\begin{array}{c}1 \\
54500000 \\
\end{array}$ \\
\hline \multirow[t]{13}{*}{ Year } & & Variable & Obs & Mean & Std. Dev. & Min & $\operatorname{Max}$ \\
\hline & & logey & 10188 & 14.98 & 1.16 & 10.50 & 17.81 \\
\hline & & educ & 10188 & 8.62 & 4.20 & 0 & 21 \\
\hline & & $\exp$ & 10188 & 21.24 & 13.44 & 0 & 58 \\
\hline & Women & income & 5950 & 3841820 & 5045006 & 35463 & 54800000 \\
\hline & & logey & 5950 & 14.44 & 1.31 & 10.48 & 17.82 \\
\hline & & educ & 5950 & 8.13 & 4.77 & 0 & 18 \\
\hline & & $\exp$ & 5950 & 22.05 & 14.81 & 0 & 58 \\
\hline & All & income & 16138 & 4918121 & 5835298 & 35463 & 54800000 \\
\hline & & logey & 16138 & 14.78 & 1.24 & 10.48 & 17.82 \\
\hline & & educ & 16138 & 8.44 & 4.43 & 0 & 21 \\
\hline & & $\exp$ & 16138 & 21.54 & 13.96 & 0 & 58 \\
\hline & & sex & 16138 & 0.63 & 0.48 & 0 & 1 \\
\hline
\end{tabular}

Source: IFLS 1993, 1997, 2000 and 2007, processed

Appendix 2. Rate of Return to Education with Basic Mincer Specification

\begin{tabular}{lcccc}
\hline & $\mathbf{1 9 9 3}$ & $\mathbf{1 9 9 7}$ & $\mathbf{2 0 0 0}$ & $\mathbf{2 0 0 7}$ \\
\hline educ & $0.158^{* * *}$ & $0.141^{* * *}$ & $0.134^{* * *}$ & $0.133^{* * *}$ \\
& $(0.00346)$ & $(0.00275)$ & $(0.00247)$ & $(0.00246)$ \\
$\exp$ & $0.0575^{* * *}$ & $0.0625^{* * *}$ & $0.0715^{* * *}$ & $0.0577^{* * *}$ \\
& $(0.00441)$ & $(0.00272)$ & $(0.0023)$ & $(0.00235)$ \\
$\exp 2$ & $-0.000882^{* * *}$ & $-0.000958^{* * *}$ & $-0.00107^{* * *}$ & $-0.000799^{* * *}$ \\
& $(0.00007)$ & $(0.00005)$ & $(0.00004)$ & $(0.00004)$ \\
sex & $0.472^{* * *}$ & $0.426^{* * *}$ & $0.473^{* * *}$ & $0.461^{* * *}$ \\
& $(0.0299)$ & $(0.0221)$ & $(0.0192)$ & $(0.0187)$ \\
Constant & $12.43^{* * *}$ & $12.66^{* * *}$ & $12.43^{* * *}$ & $12.65^{* * *}$ \\
& $(0.0744)$ & $(0.0446)$ & $(0.0379)$ & $(0.0405)$ \\
\hline Ob s e r v a - & & & & \\
tions & 7,432 & 9,505 & 13,844 & 16,138 \\
R-squared & 0.294 & 0.29 & 0.253 & 0.215 \\
\hline
\end{tabular}

Note: Dependent variable is income in year. The first line indicates coefficient value where the sign $* * *$ is significant $1 \%, * *$ is significant $5 \%$ and $*$ is significant $10 \%$. The second line indicates error standard. 
Avalaible online at http://journals.ums.ac.id

Jurnal Ekonomi Pembangunan, 17 (1), Juni 2016, 62-73

Appendix 3. Rate of return to Education with Pool Data and Cohort

\begin{tabular}{ccccccc}
\hline & \multicolumn{2}{c}{ Men } & \multicolumn{2}{c}{ Women } & \multicolumn{2}{c}{ All } \\
\hline Old & Young & Old & Young & Old & Young \\
\hline Educ & $0.161^{* * *}$ & $0.152^{* * *}$ & $0.156^{* * *}$ & $0.179^{* * *}$ & $0.157^{* * *}$ & $0.163^{* * *}$ \\
& $(0.00584)$ & $(0.00585)$ & $(0.00916)$ & $(0.00786)$ & $(0.00488)$ & $(0.00472)$ \\
Educ*year & $-0.0184^{* * *}$ & $-0.00433^{* *}$ & $-0.00951^{* * *}$ & -0.00412 & $-0.0144^{* * *}$ & $-0.00418^{* * *}$ \\
& $(0.00183)$ & $(0.00189)$ & $(0.00275)$ & $(0.00256)$ & $(0.00151)$ & $(0.00153)$ \\
Exp & 0.00244 & $0.102^{* * *}$ & -0.0101 & $0.0446^{* * *}$ & -0.00569 & $0.0770^{* * *}$ \\
& $(0.00783)$ & $(0.00413)$ & $(0.0114)$ & $(0.00495)$ & $(0.00639)$ & $(0.0032)$ \\
Exp2 & $-0.00028^{* * *}$ & $-0.00192^{* * *}$ & 0.00002 & -0.000284 & -0.00012 & $-0.00122^{* * *}$ \\
& $(0.00010)$ & $(0.00014)$ & $(0.00014)$ & $(0.00017)$ & $(0.00008)$ & $(0.00011)$ \\
Year & $0.191^{* * *}$ & $0.0311^{*}$ & $0.108^{* * *}$ & 0.0024 & $0.153^{* * *}$ & 0.0208 \\
& $(0.0153)$ & $(0.018)$ & $(0.0187)$ & $(0.0248)$ & $(0.0119)$ & $(0.0146)$ \\
Sex & & & & & $0.493^{* * *}$ & $0.445^{* * *}$ \\
Constant & $13.95^{* * *}$ & $12.62^{* * *}$ & $13.60^{* * *}$ & $12.39 * * *$ & $13.59^{* * *}$ & $12.27^{* * *}$ \\
& $(0.159)$ & $(0.0606)$ & $(0.244)$ & $(0.0812)$ & $(0.132)$ & $(0.0491)$ \\
R-squared & 12,077 & 17,429 & 7,217 & 10,196 & 19,294 & 27,625 \\
\hline
\end{tabular}

Note: Dependent variable is income in year. The first line indicates coefficient value where the sign $* * *$ is significant $1 \%,{ }^{* *}$ is significant $5 \%$ and $*$ is significant $10 \%$. The second line indicates error standard. 